\title{
Patient Satisfaction with Flexible Acrylic Compared to Conventional Polymethylmethacrylate Obturators (Randomized, Clinical Study)
}

\author{
Ahmed A. Elwahed Shaaban "1, Bassem Mohsen A. Elhamed ${ }^{1}$, Aya Mohamed Fawzy ${ }^{1}$, \\ Ahmed Amin Moselhy ${ }^{2}$
}

Codex : 01/2021/04

Aadj@azhar.edu.eg

\section{KEYWORDS}

Obturator functioning scale, Polymethyl methacrylate,

flexible acrylic resin,

Flexible acrylic resin obturators,

PMMA obturators

1. Department of Prosthodontic, Faculty of dentistry, Future university, Cairo, Egypt .

2. Department of prosthodontics, Military Medical Academy, Cairo, Egypt .

* Corresponding Author e-mail: Ahmed.shaban@rocketmail.com

\section{ABSTRACT}

Aim: The selection of the appropriate denture base material for obturator fabrication is essential as it significantly affects the overall clinical outcomes. Flexible acrylic resin obturators provide an excellent alternative to the traditionally used PMMA obturators, due to its impeccable esthetics, comfort, retention and adaption to the constantly mobile oral tissues. Subjects and methods: This is a randomized, crossover study. Patients included in the study were randomly allocated into one of two groups (group $\mathrm{AB}$ and group $\mathrm{BA}$ ). Each of the patients included in the study had a conventional PMMA (device A) and a flexible (device B) obturator constructed for them to be used sequentially each for two weeks. The patients filled a 5-point Likert scale obturator functioning scale after two weeks of using each type of obturator. The data were statistically analyzed. Results: The results of this study demonstrated that device $\mathrm{B}$ which is an obturator made of flexible acrylic resin provided a significantly higher patient satisfaction compared to device A, which is constructed of PMMA. Conclusion: Flexible acrylic resin obturators are more satisfying to maxillectomy patients than PMMA obturators.

\section{INTRODUCTION}

Prosthetic rehabilitation of maxillectomy patients mainly aims to reinstate their quality of life to near-normal. Patients with acquired maxillary defects differ from those afflicted with congenital defects due to the abrupt change associated with the former ${ }^{(1)}$. The defects lead to a reduction in the quality of life due to establishment of oroantral and oronasal communication with subsequent difficulties in mastication, hyper-nasal speech, fluid leakage and esthetic concerns, leading to a reduction in quality-of-life of the patient ${ }^{(2)}$. Early management is thus key in restoring function and improving the patient's self-esteem and psychological well-being ${ }^{(3)}$.

Key to attaining the desired outcomes in the rehabilitation of maxillectomy patients is the utilization of an obturator ${ }^{(3)}$. The selection of the appropriate denture base material for obturator fabrication is 
essential as it significantly affects the overall clinical outcomes. Vulcanite materials were used as denture base material up-to 1937, when methyl methacrylate polymers (PMMA) resins were introduced and became the denture base material of choice, for years to follow ${ }^{(4)}$. PMMA gained wide recognition due to its distinctive properties, including its low density, ease of manipulation, cost-effectiveness and acceptable esthetics ${ }^{(2)}$.

However, PMMA is not without flaws, the most prominent of which is its fracture due to water sorption and inadequate impact and flexural strength, especially noted when used as a denture base material ${ }^{(5)}$. Moreover, there are particular disadvantages associated with PMMA obturators, such as difficulty with undercuts due to PMMA rigidity which may also cause ulcerations on the supporting tissues, polymerization shrinkage and PMMA obturators tend to become heavy when used with large defects. Recently, a large body of research is focused on chemical modification and mechanical reinforcement of PMMA to overcome its drawbacks and improve its properties. Likewise, PMMA-based biocomposites teamed with epoxy resins, butadiene styrene or polyamide have been described to enhance the impact strength of PMMA ${ }^{(6)}$.

In the 1950s, Nylon - a generic name for certain types of thermoplastic polymers Polyamide resinwas proposed as a novel flexible denture base material. Flexible denture base material are produced by a diamine $\mathrm{NH} 2-(\mathrm{CH} 2) 6-\mathrm{NH} 2$ and a dibasic acid, $\mathrm{CO} 2 \mathrm{H}-(\mathrm{CH} 2) 4-\mathrm{COOH}$ condensation reaction. In contrast to the amorphous PMMA, Nylon used in flexible dentures is a crystalline polymer ${ }^{(7)}$. This property accounts for its insolubility in solvents, as well as its high heat resistance, strength, elasticity and ductility. Flexible dentures provide an excellent alternative to the traditionally used PMMA obturators, which provide impeccable esthetics, comfort retention and adaption to the constantly mobile oral tissues ${ }^{(3,6)}$.
"Health-related quality of life" (HRQOL) and Treatment satisfaction have recently been recognized as patient-based outcome measures in context of prosthetic rehabilitation of patients treated from head and neck cancer ${ }^{(4-8)}$. The aim of this study was to compare maxillectomy patient satisfaction when using obturators constructed using PMMA and Flexible acrylic, which has not been reported previously in literature, to the best of our knowledge.

\section{PATIENTS/MATERIALS AND METHODS}

\section{Study design}

This was a randomized, crossover experiment, comprising two groups. Patients included in the study were randomly allocated into one of the two groups. Each of the patients included in the study had a conventional PMMA (device A) and a (device B) flexible obturator constructed. Patients were then randomly allocated into 2 groups designated as follows;

Group AB (receiving device A for two weeks followed by device B)

Group BA (receiving device B for two weeks followed by device A)

This study has been performed in accordance to "The Code of Ethics of the World Medical Association" for experiments involving humans ${ }^{(9)}$. The experimental design and study protocol were approved by the ethical committee of the Faculty of Oral and Dental Medicine, Future University in Egypt.

\section{Patient enrollment}

Nine hemi-maxillectomy patients that referred to the prosthodontics department of the Faculty of Oral and Dental Medicine, Future University in Egypt (FODM, FUE) for prosthetic rehabilitation between January 2017 and September 2019 were asked to participate in this study. All patients were clinically examined and were asked to fill out 
a detailed questionnaire for this study. The questionnaire contained information about; personal data, medical history and dietary habits. All participants were fully informed about the study and signed a detailed informed-consent. Brown's classification was used to determine the defect size in the maxilla/midface ${ }^{(10)}$. Patients were excluded if they cognitive impairment, had recurrences or serious co-morbidity. Out of the nine patients eight met the inclusion criteria and one patient was excluded due to unstable heart condition. The patients included were 3 male and 5 female, the average age of these patients was \pm 53.1 .

\section{Construction of obturators}

Primary Impressions (maxillary and mandibular) were made for each patient( Fig 1,2 ).

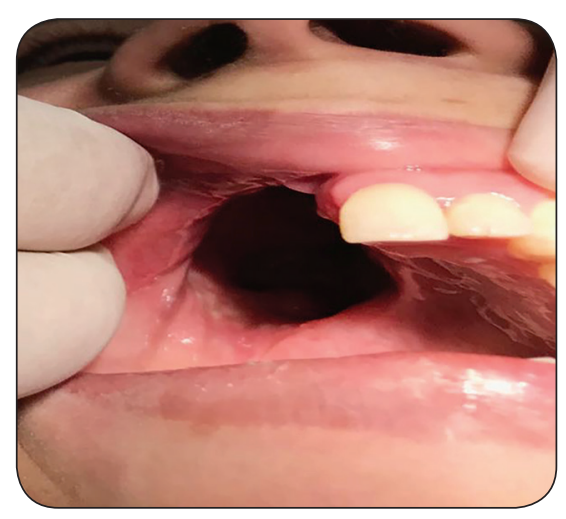

Fig. (1) Hemimaxillectomy

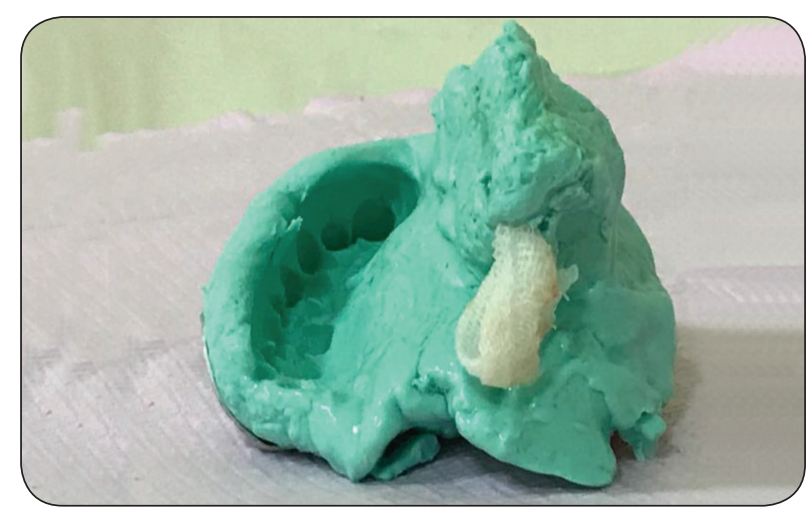

Fig. (2) Primary impression

Special trays were fabricated using cold cure acrylic resin (Acrostone, Egypt), secondary impres- sions were then taken using a medium consistency, one-step vinyl-siloxan-ether (Identium Medium, Kettenbach, Germany)( Fig 3 ).

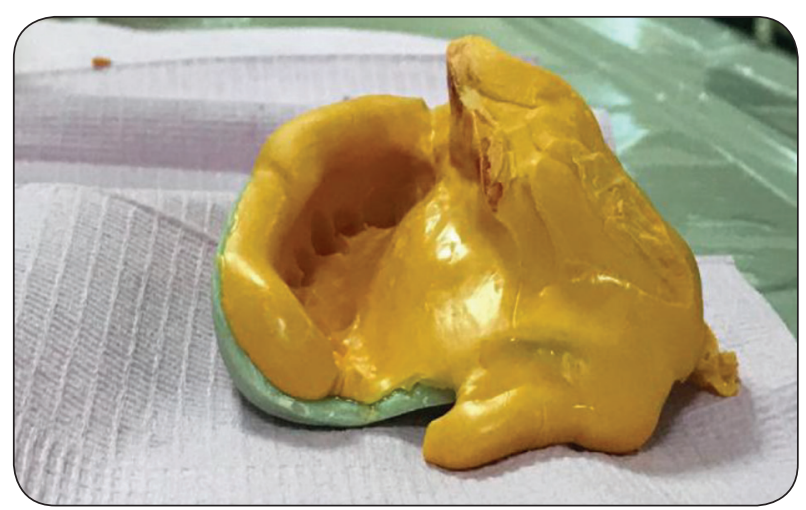

Fig. (3) Secondry rubber base impression

Secondary impressions were then poured twice; using conventional stone suitable for heat cured acrylic resin (device A) and using special (expansion stone) for constructing the injection molded (flexible, device B)(Fig 4)

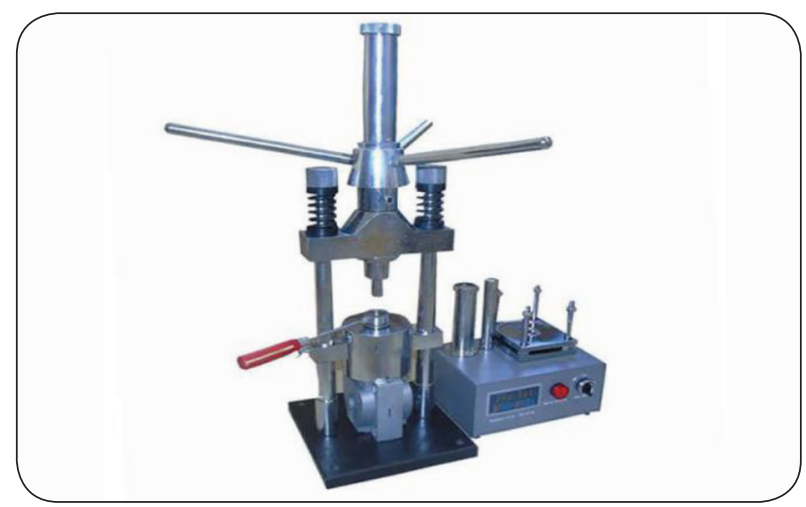

Fig. (4) Injection device

Obturators to compensate for expected volumetric contraction associated with cooling. Acrylic teeth were then subsequently added to both obturators. All patients were fitted with two obturators; (Fig 5,6).

One fabricated using heat cured acrylic resin (Acrostone, Egypt) (device A), and one fabricated using injection molded thermoplastic acrylic resin (Biodentaplast material, Bredent, Senden/ Witzighausen, Germany), (device B). Patients were blinded to the nature of the obturator received. This design was done in accordance to Nawar N.H., and Wassel M.O. , $2016^{(11)}$. 


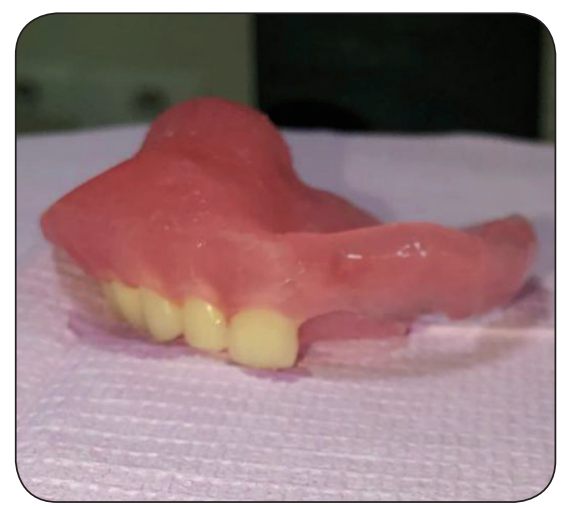

Fig. (5) Final obturator

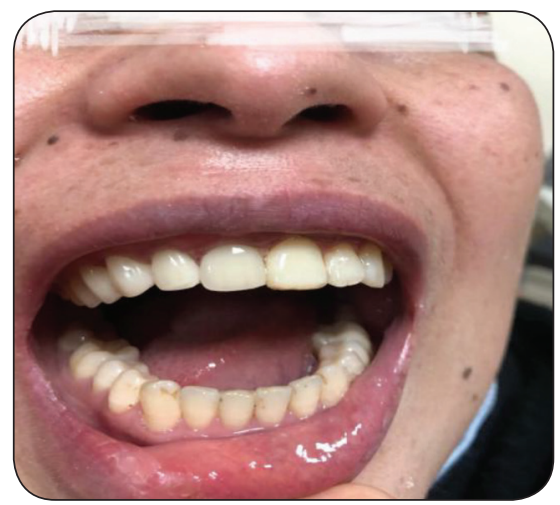

Fig. (6) Final obturator in patient mouth

\section{Subjective assessment of the devices}

Evaluation of the patients satisfaction with the performance of either of the tested obturators was done using an Obturator Function Scale ${ }^{(12)}$ (translated into Arabic) with patient's responses recorded on a 5-point Likert Scale (table 1).

Points 1 and 2 stood for 'not at all difficult' and 'a little difficult' on the scale and were considered as 'No Difficulty. Points 3, 4 and 5 stood for 'somewhat difficult', 'very much difficult' and 'extremely difficult' respectively and were considered as 'Difficulty'. The questions included difficulty in chewing, leakage while swallowing, voice different from before surgery, difficulty in talking in public, nasal speech, difficulty in pronouncing words, speech difficult to understand, difficulty in talking on phone, dry mouth, dissatisfaction with looks, noticeable clasps, numb upper lip, avoidance of family and social events, difficulty in inserting the obturator and funny looking upper lip. Patients response from 1-2 were considered as 'No difficulty' and 3-5 were considered as having 'Difficulty'. The scores on the Likert scale were considered inversely proportional to the functioning of the obturator.

Table (1) Obturator function scale

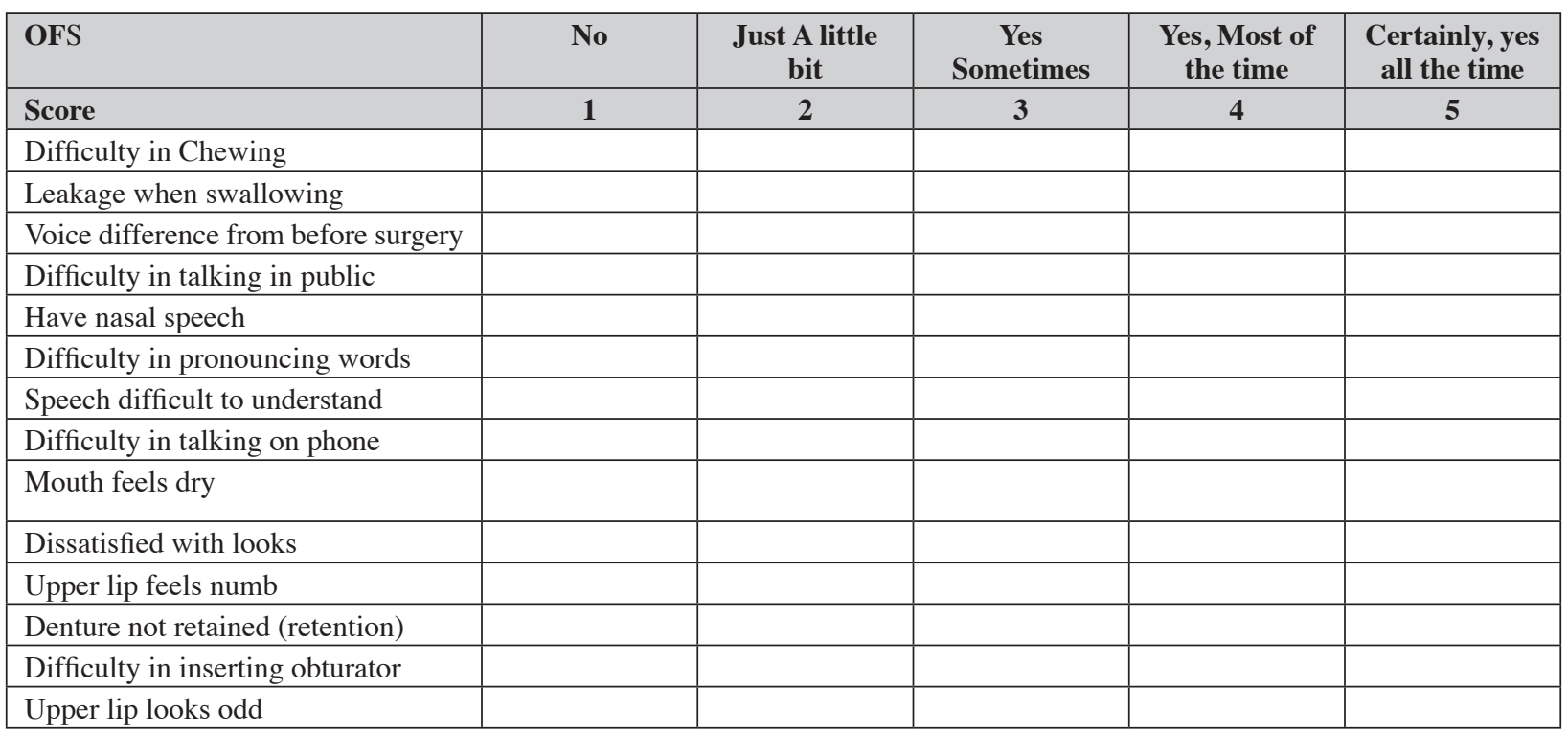

The assessment was performed after 2 weeks of delivery for each type of obturator (device A and B) 


\section{Statistical assessment}

This is study was performed using a crossover design in which the study participants were classified as group $\mathrm{AB}$ (starting the obturator $\mathrm{A}$ for two weeks then shifted to obturator $\mathrm{B}$ while the reverse was for group BA. Each participant subjected to interview questionnaire with 5-point Likert scale. The 5 points are: No problem, Just a little bit, Yes sometimes, Yes most of times, Certainly yes all the time. The questionnaire included 14 questions. We asked the participant to select one for each question.

The questionnaire was distributed to all participants after two weeks (first period) then re-distributed again after 4 weeks i.e. two weeks from the first period. A priori scoring system was developed. For each question there was a score ranged from 1 to 5 ( 1 for No problem, 2 for just a little, 3 for yes sometimes, 4 for yes most of time, 5 for yes all the time). Accordingly, the total score of the questionnaire (14 questions) for each study period ranged between 14 and 70 . The lower the score is the better of patient's compliance and satisfaction.

As the design is crossover one, we first tested the effect of carryover. We used unpaired t-test to check the assumption of negligible carryover effect. Then, we compare the effect of treatment. Also, we tested the interaction between the period (time) and the treatment effect. Descriptive statistics: For qualitative data, we used frequency and percentage while for quantitative data we used mean and standard deviation (SD).

All calculated scores were tested for normality distribution using one sample Kolmogorov Smirnov test. All scores showed normal distribution; therefore, we used test of significance for normal distributed data e.g. t-test for two independent groups (means) i.e. unpaired t-test. For qualitative data, we used Fisher's Exact test as a test of significant. $\mathrm{P}$ value $<0.05$ was considered significant. Statistical analysis was carried by Microsoft Excel and IBMSPSS Statistical Package version 22.

\section{RESULTS}

The results of the present study showed that during the first 2 weeks group BA showed significantly more patient satisfaction than group $\mathrm{AB}$ regarding speech being difficult to understand, difficulty in talking on phone and mouth feeling dry, while the rest of the items on the OFS exhibited a non-significant difference between responses of both groups. (Table 2)

On comparing both groups during period 2 (the second two weeks of the trial), there was found to be a significantly better patient satisfaction in group $\mathrm{AB}$ regarding difficulty in chewing, voice difference from before, difficulty in talking on phone, avoiding family events and difficulty in inserting obturator when compared to group BA responses during the same period. (Table 3)

On comparing the two groups using T-test for two independent means, it was found that the Mean Total Score after period 1 and mean total Score after period 2 exhibited highly significant differences between the two tested groups $(\mathrm{p} \leq 0.05)$. The sum of scores through the overall experimental period in both groups was found to be insignificant, which implies the absence of any carry over effect in this cross over study. Device B was found to be significantly more satisfying to the patients when compared to device A (Table 4, fig 7 ) 
Table (2) Comparison between the two obturators after the end of the second week (Period 1)

\begin{tabular}{|c|c|c|c|c|c|}
\hline \multirow{3}{*}{ Variables } & \multicolumn{4}{|c|}{ Period 1 (First Two weeks) } & \multirow{3}{*}{$\mathrm{P}$ value } \\
\hline & \multicolumn{2}{|c|}{ Group BA } & \multicolumn{2}{|c|}{ Group AB } & \\
\hline & $\begin{array}{l}\text { No/ or } \\
\text { a little bit } \\
\text { No. }(\%)\end{array}$ & $\begin{array}{l}\text { Yes sometimes/ } \\
\text { most or all time } \\
\text { No. }(\%)\end{array}$ & $\begin{array}{c}\mathrm{No} / \text { or } \\
\text { a little bit } \\
\text { No. }(\%)\end{array}$ & $\begin{array}{l}\text { Yes sometimes/ } \\
\text { most or all time } \\
\text { No. }(\%)\end{array}$ & \\
\hline Difficulty in Chewing & $3(75.0)$ & $1(25.0)$ & $0(0.0)$ & $4(100.0)$ & 0.143 \\
\hline Leakage when swallowing & $4(100.0)$ & $0(0.0)$ & $2(50.0)$ & $2(50.0)$ & 0.429 \\
\hline Voice difference from before & $1(25.0)$ & $3(75.0)$ & $0(0.0)$ & $4(100.0)$ & 1.000 \\
\hline Difficulty in talking in public & $4(100.0)$ & $0(0.0)$ & $1(25.0)$ & $3(75.0)$ & 0.143 \\
\hline Have nasal Speech & $3(75.0)$ & $1(25.0)$ & $0(0.0)$ & $4(100.0)$ & 0.143 \\
\hline Difficulty in pronouncing words & $3(75.0)$ & $1(25.0)$ & $0(0.0)$ & $4(100.0)$ & 0.143 \\
\hline Speech Difficult to understand & $4(100.0)$ & $0(0.0)$ & $0(0.0)$ & $4(100.0)$ & 0.029 \\
\hline Difficulty in talking on phone & $4(100.0)$ & $0(0.0)$ & $0(0.0)$ & $4(100.0)$ & 0.029 \\
\hline Mouth feels dry & $4(100.0)$ & $0(0.0)$ & $0(0.0)$ & $4(100.0)$ & 0.029 \\
\hline Dissatisfied with looks & $3(75.0)$ & $1(25.0)$ & $0(0.0)$ & $4(100.0)$ & 0.143 \\
\hline Upper lip feels numb & $2(50.0)$ & $2(50.0)$ & $4(100.0)$ & $0(0.0)$ & 0.429 \\
\hline Denture not retained (retention) & $3(75.0)$ & $1(25.0)$ & $0(0.0)$ & $4(100.0)$ & 0.143 \\
\hline Difficulty in inserting obturator & $3(75.0)$ & $1(25.0)$ & $0(0.0)$ & $4(100.0)$ & 0.143 \\
\hline Upper lip looks odd & $4(100.0)$ & $0(0.0)$ & $3(75.0)$ & $1(25.0)$ & 1.000 \\
\hline
\end{tabular}

N.B: All comparisons were done using Fisher's Exact test. Red and Bold data are significant

Table (3) Comparison between the two obturators after the end of the fourth week (Period 2)

\begin{tabular}{|c|c|c|c|c|c|}
\hline \multirow[b]{3}{*}{ Variables } & \multicolumn{4}{|c|}{ Period 2 (Second Two weeks) } & \multirow[b]{3}{*}{$\mathrm{P}$ value } \\
\hline & \multicolumn{2}{|c|}{ Group BA } & \multicolumn{2}{|c|}{ Group AB } & \\
\hline & $\begin{array}{c}\mathrm{No} / \text { or } \\
\text { a little bit } \\
\text { No. }(\%)\end{array}$ & $\begin{array}{l}\text { Yes sometimes/ } \\
\text { most or all time } \\
\text { No. }(\%)\end{array}$ & $\begin{array}{c}\mathrm{No} / \text { or } \\
\text { a little bit } \\
\text { No. }(\%)\end{array}$ & $\begin{array}{l}\text { Yes sometimes/ } \\
\text { most or all time } \\
\text { No. }(\%)\end{array}$ & \\
\hline Difficulty in Chewing & $0(0.0)$ & $4(100.0)$ & $4(100.0)$ & $0(0.0)$ & 0.029 \\
\hline Leakage when swallowing & $2(50.0)$ & $2(50.0)$ & $4(100.0)$ & $0(0.0)$ & 0.429 \\
\hline Voice difference from before & $0(0.0)$ & $4(100.0)$ & $4(100.0)$ & $0(0.0)$ & 0.029 \\
\hline Difficulty in talking in public & $1(25.0)$ & $3(75.0)$ & $4(100.0)$ & $0(0.0)$ & 0.143 \\
\hline Have nasal Speech & $1(25.0)$ & $3(75.0)$ & $4(100.0)$ & $0(0.0)$ & 0.143 \\
\hline Difficulty in pronouncing words & $1(25.0)$ & $3(75.0)$ & $4(100.0)$ & $0(0.0)$ & 0.143 \\
\hline Speech Difficult to understand & $1(25.0)$ & $3(75.0)$ & $4(100.0)$ & $0(0.0)$ & 0.143 \\
\hline Difficulty in talking on phone & $0(0.0)$ & $4(100.0)$ & $4(100.0)$ & $0(0.0)$ & 0.029 \\
\hline Mouth feels dry & $1(25.0)$ & $3(75.0)$ & $3(75.0)$ & $1(25.0)$ & 0.486 \\
\hline Dissatisfied with looks & $1(25.0)$ & $3(75.0)$ & $4(100.0)$ & $0(0.0)$ & 0.143 \\
\hline Upper lip feels numb & $4(100.0)$ & $0(0.0)$ & $3(75.0)$ & $1(25.0)$ & 1.000 \\
\hline denture not retained (retention) & $0(0.0)$ & $4(100.0)$ & $4(100.0)$ & $0(0.0)$ & 0.029 \\
\hline Difficulty in inserting obturator & $0(0.0)$ & $4(100.0)$ & $4(100.0)$ & $0(0.0)$ & 0.029 \\
\hline Upper lip looks odd & $3(75.0)$ & $1(25.0)$ & $3(75.0)$ & $1(25.0)$ & 1.000 \\
\hline
\end{tabular}

N.B: All comparisons were done using Fisher's Exact test. Red and Bold data are significant 
Table (4) Comparison between both groups in each period and in both periods (total sum and average) and between device $A$ and device $B$.

\begin{tabular}{|c|c|c|c|c|}
\hline Study groups/ devices & $\begin{array}{c}\text { Total Score } \\
\text { after period } 1 \\
\text { Mean } \pm \text { SD }\end{array}$ & $\begin{array}{c}\text { Total Score } \\
\text { after period } 2 \\
\text { Mean } \pm \text { SD }\end{array}$ & $\begin{array}{l}\text { Total sum scores of } \\
\text { the two periods } \\
\text { Mean } \pm \text { SD }\end{array}$ & $\begin{array}{c}\text { Average of the scores } \\
\text { of the two periods } \\
\text { Mean } \pm \text { SD }\end{array}$ \\
\hline Group BA & $\mathbf{2 2 . 5 0} \pm 8.81$ & $43.75 \pm 5.19$ & $66.25 \pm 10.24$ & 33.125 .12 \\
\hline Group AB & $\mathbf{5 5 . 5 0} \pm 4.04$ & $\mathbf{1 6 . 7 5} \pm 3.59$ & $72.25 \pm 4.86$ & 36.122 .43 \\
\hline $\begin{array}{l}\text { T-test for two } \\
\text { independent means }\end{array}$ & 6.81 & 8.55 & 1.06 & 1.06 \\
\hline P value & $\begin{array}{c}<0.001 \\
\text { highly significant }\end{array}$ & $\begin{array}{c}<0.001 \\
\text { highly significant }\end{array}$ & $\begin{array}{c}0.331 \\
\text { insignificant }\end{array}$ & $\begin{array}{c}0.331 \\
\text { insignificant }\end{array}$ \\
\hline Device A & -- & -- & $49.63 \pm 7.62$ & -- \\
\hline Device B & -- & -- & $19.63 \pm 6.95$ & -- \\
\hline $\begin{array}{l}\text { T-test for two } \\
\text { independent means }\end{array}$ & -- & -- & 6.81 & -- \\
\hline$P$ value & -- & -- & $\begin{array}{l}<0.001 \text { highly } \\
\text { significant }\end{array}$ & -- \\
\hline
\end{tabular}

N.B: The lower the mean score; the better of patient compliance and satisfaction

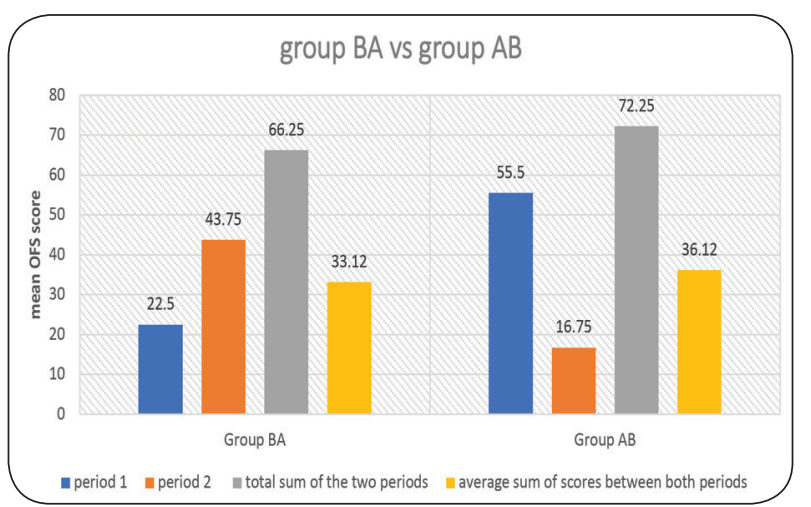

Fig. (7) Chart showing the score comparisons between the studied groups.

\section{DISCUSSION}

Cancer diagnosis followed by maxillectomy is a life turning event. Patients suddenly find themselves unable to perform the daily physiological functions they did with ease, as well as having to deal with the immediate change in appearance and facial contour following the surgery. Prosthetic rehabilitation is thus of great value to restore, as much as possible, the compromised function and appearance ${ }^{(8,10)}$. PMMA has been used for years as the material of choice for obturator construction, however, it is not ideal from all aspects. It has been reported to be 'unsatisfying' in several studies, due to its difficult insertion, stiffness, roughness on the underlying soft tissues, and low fractural strength ${ }^{(2-6)}$.

For this reason, this study was performed to evaluate patient satisfaction when using an obturator constructed from PMMA versus one that is made from flexible acrylic resin, using an $\mathrm{OFS}^{(6)}$. To avoid prejudice and any carry over effect or personal variations the same patient was given both devices, each to be worn for two weeks and was blinded to the type of device he/she received. When comparing the overall scores for each group through-out the experimental period, it was found that the results were insignificant and hence the absence of any carryover effect from period 1 to period 2.

The results of this study demonstrated as well that device $\mathrm{B}$ which is an obturator made of flexible acrylic resin provided a significantly higher patient satisfaction compared to device A which was constructed of PMMA. This could be explained 
by the fact that the flexible resin has a high modulus of elasticity which allows its utilization in the manufacture of retentive clasps and support elements for the obturator, which lock the available remaining dentition ${ }^{(13)}$. Stress distribution is also a fundamental advantage fulfilled by the flexibility of the obturator parts, which act as a stress breakers. Moreover, in the long term, the flexibility of the obturator appears to act as a tissue conditioner on the tissue-supported saddles, without exerting a significant stress load on the abutment teeth. Last but not least, flexible obturators decrease the leverage effects of its extensions while preserving support and retention ${ }^{(14)}$.

It should also be noted that during period 2, group $\mathrm{AB}$ were significantly more satisfied by the ease of insertion of the obturator compared group BA having the PMMA obturator. This may be attributed to the fact that group $A B$ were very satisfied with the flexibility and ease of insertion as there is much lower resistance and roughness compared to the PMMA obturator they just stopped using. The results of this study demonstrate that here is higher patient satisfaction associated with the use of flexible acrylic resin obturators when compared to PMMA obturators among maxillectomy patients.

\section{CONCLUSION}

Flexible acrylic resin obturators are more satisfying to maxillectomy patients than PMMA obturators

\section{REFERENCES}

1. Omo, J., Sede, M., Enabulele, J. (2014) Prosthetic rehabilitation of patients with maxillary defects in a nigerian tertiary hospital., Ann Med Health Sci Res., Vol. 4(4), pp. 630-633.

2. Handschel, R., Depprich, C., Naujoks, D. (2010) ,Evaluation of the quality of life of patients with maxillofacial defects after prosthodontic therapy with obturator prostheses. International Journal of Oral and Maxillofacial Surgery, Vol.40(1), pp. 71-79.

3. Taqi Fadhil SM and Mumcu E. (2019), Rehabilitation of a patient with palatal defect- A case report. J Surg Surgical Res., Vol. 5(2), pp. 093-096.
4. Shekhawat, S., Pankaj, N., Himanshu, G., (2013) New Era in Denture Base Resins: A Review. Dental Journal of Advance Studies ,pp. DOI: 10.1055/s-0038-1671969.

5. Chugh, N., Sheriger, P., Balakrishnan, D., Ichalangod, A.N. (2020),To Compare the Flexural Properties of Three Commercially Available Heat Cure Denture Base Resins After Water Immersion Over a Period of Three Months: An in Vitro Study. Indian Journal of Public Health Research \& Development, Vol. 11.

6. Sahar, A. and NajiJafarzadeh, K. (2018), Recent Advances and Future Perspectives for Reinforcement of Poly(methyl methacrylate) Denture Base Materials: A Literature Review. Journal of dental education, Vol. 5.

7. 7. Nguyen 1., G., Kopperud, H., M., Olio, M. (2017), Water sorption and solubility of polyamide denture base materials Acta Biomaterialia Odontologica Scandinavica , pp. 47-52.

8. Singh, M., Limbu, I. K., Parajuli, P. K., and Singh, R. K. (2020), Definitive Obturator Fabrication for Partial Maxillectomy Patient. Clinical Oral Implants Research , Vol. 21,pp. 405-416.

9. RICKHAM, P P. (1964), Code of ethics of the world medical association. 5402, British medical journal, Vol. 2, pp. 177-177.

10. Buurman, D. J., Speksnijder, C. M., Engelen, B. H., Kessler, P. ( 2020), Masticatory performance and oral health-related quality of life in edentulous maxillectomy patients: A cross-sectional study to compare implantsupported obturators and conventional obturators., Clinical Oral Implants Research, Vol. 31, pp. 405-416.

11. Nawar, N. H., and Wassel, M. O. (2016), Effects of flexible acrylic obturator versus heat cured acrylic obturator on speech quality of children with congenital cleft palate., Egyptian dental journal, Vol. 62, p. 1289.

12. Kreeft, A. M., Krap, M., Wismeijer, D., Speksnijder, C. M., Smeele, L. E., Bosch, S. D., Balm, A. J. M. (2012), Oral function after maxillectomy and reconstruction with an obturatorInternational journal of oral and maxillofacial surgery, Vol. 41, pp. 1387-1392.

13. Swapnil Parlani, Benaiffer Agarwal, Anurag Malaiya. (2018), Evaluation of Flexural Modulus of Flexible Denture Base Material kept in Water, Denture Cleanser, Artificial Saliva, and Open Air for Different Time Intervals: An in vitro Study. International Journal of Prosthodontics and Restorative Dentistry, Vol. 8, pp. 54-58.

14. Chandra, T.V ., and Ramasamy, J. (2020), An innovative sectional silicone obturator in a patient with partial maxillectomy: A Case report, J Indian Prosthodont Soc., Vol. 20, pp. 115-119. 
النشر الرسمي لكلية طب الأسنان جامعة الأزهر أسيوط الكاية

مصر جامعة

\title{
رضا المريض عن الأكريليك المرن مقارنةً بأجهزة ختم الاتصال

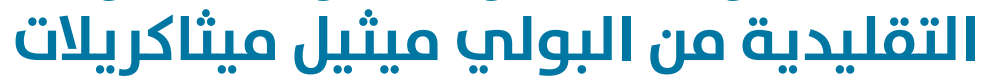 ( دراسة سريرية عشوائية البولية مئية
}

\author{
احمد عبدالواحد شعبان1*, بسمه محسن عبدالحميد 1, ايله محمد فوزى1,احمد امين مصلحى2

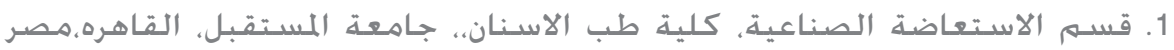

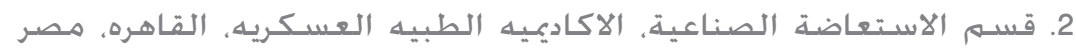 \\ AHMED.SHABAN@ROCKETMAIL.coM *
}

الملخص :

الهدف: دراسة رضا المريض عن الأكريليك المرن مقارنةً بأجهزة ختم الاتصال التقلبدية من البولي ميثيل ميثاكريلات.

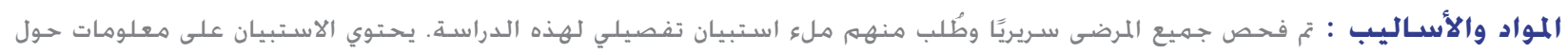

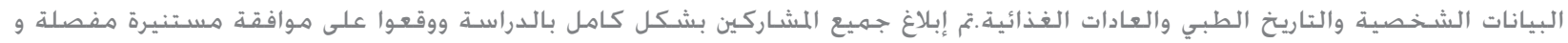

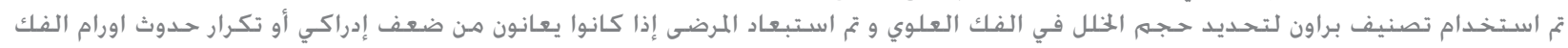

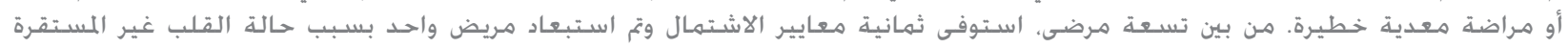

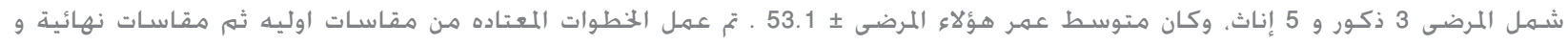

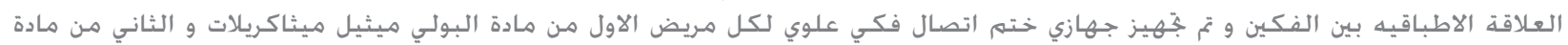

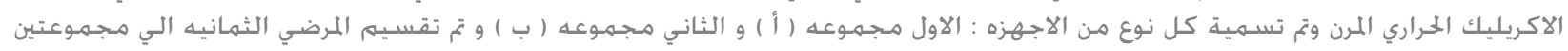

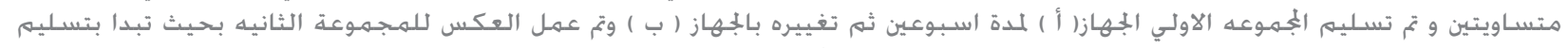

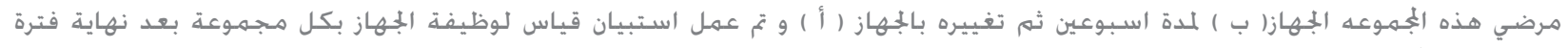

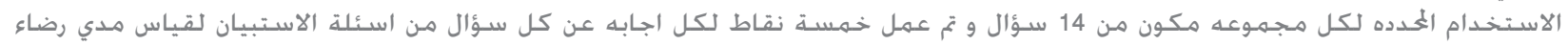
المريض و تم وضع النتائج في برامج احمد احصائية

النتائج :اشارت بشكل واضح الي زيادة رضاء المرضي في نهاية فترة استخدامهم للاجهزه المصنوعه من الاكريليك الحراري المرن بشكل اكبر من الاجهزه المصنوعه من البولي ميثيل ميثاكريلات خلال مدة الدراسة.

الخلاصة: الاجهزه المصنوعه من الاكريليك الحراري المرن افضل بشكل اكبر من الاجهزه المصنوعه من البولي ميثيل ميثاكريلات من حبث رضاء المريض بعد تركيبها.

الكلمات المفتاحية: مقياس الرضاء الوظيفى، الاجهزه المصنوعه من البولي ميثيل ميثاكريلات, الاجهزه المصنوعه من الاكريليك الحراري المرن, رضاء المريض، اجهزه خته الاتصال المفال المال 